\title{
Marinilactibacillus psychrotolerans gen. nov., sp. nov., a halophilic and alkaliphilic marine lactic acid bacterium isolated from marine organisms in temperate and subtropical areas of Japan
}

\author{
Correspondence \\ Morio Ishikawa \\ mori-01@pc4.so-net.ne.jp
}

\author{
Morio Ishikawa, Kazuyuki Nakajima, Miyoko Yanagi, Yasushi Yamamoto \\ and Kazuhide Yamasato
}

Department of Fermentation Science, Faculty of Applied Bio-Science, Tokyo University of Agriculture, 1-1 Sakuragaoka 1-chome, Setagaya-ku, Tokyo 156-8502, Japan

\begin{abstract}
A novel marine lactic acid rod bacterium has been described for eight strains isolated from living and decomposing marine organisms collected from temperate and subtropical areas of Japan. The isolates were Gram-positive, catalase-negative, non-sporulating and motile with peritrichous flagella. They were slightly halophilic, highly halotolerant and alkaliphilic; the optimum $\mathrm{NaCl}$ concentration for growth was $2 \cdot 0-3 \cdot 75 \%(\mathrm{w} / \mathrm{v})$ with a range from 0 to $17 \cdot 0-20 \cdot 5 \%$ (depending on the strain); the optimum $\mathrm{pH}$ was between 8.0 and 9.5 with a range from 6.0 to $10 \cdot 0$. They were psychrotolerant, growing well at $-1 \cdot 8^{\circ} \mathrm{C}$ with a maximum at $40-45^{\circ} \mathrm{C}$ and the optimum at $37-40^{\circ} \mathrm{C}$. Lactate yields were $87-100 \%$ per consumed glucose; the residual products were formate, acetate and ethanol with a molar ratio of approximately $2: 1: 1$. The product composition was markedly affected by the $\mathrm{pH}$ of fermentation medium; at higher $\mathrm{pH}$, the yield of lactate decreased (60-65\% at $\mathrm{pH} 9 \cdot 0)$ and that of other products increased conversely. The cell-wall peptidoglycan type was type A4 $\beta$, Orn-D-Glu, whereas that of the genus Alkalibacterium, the phylogenetically closest lactic acid bacterium, was type A4 $\beta$, Orn-D-Asp. The major cellular fatty acids were $\mathrm{C} 16: 0, \mathrm{C} 16: 1 \Delta 9, \mathrm{C} 18: 0$ and $\mathrm{C} 18: 1 \Delta 9$ (oleic acid). The $\mathrm{G}+\mathrm{C}$ content of the DNA was 34.6-36.2 mol\%. The eight isolates were phenotypically homogeneous and formed a single genomic species. The $16 \mathrm{~S}$ rRNA gene sequence analysis indicated that the isolates constituted an independent phylogenetic lineage within the radiation of lactic acid bacteria with $96 \cdot 2 \%$ similarity to the genus Alkalibacterium. The secondary structure and the nucleotide sequence of the V6 region of the $16 \mathrm{~S}$ rRNA were characteristic of the organism among other related lactic acid genera. On the bases of phenotypic and phylogenetic distinctness, the organism was proposed to belong to a new genus and species, Marinilactibacillus psychrotolerans gen. nov., sp. nov. The type strain, M13-2 ${ }^{\top}(\mathrm{G}+\mathrm{C}=36 \cdot 2 \mathrm{~mol} \%)$, has been deposited in the IAM, NBRC, NCIMB and NRIC culture collections as IAM $14980^{\top}$, NBRC $100002^{\top}$, NCIMB $13873^{\top}$ and NRIC $0510^{\top}$, respectively.
\end{abstract}

\section{INTRODUCTION}

Marine environments are characterized by the presence of salts (total salts concentration $3 \cdot 2-3 \cdot 8 \%, \mathrm{w} / \mathrm{v}$ ) and by an alkaline reaction (surface water $\mathrm{pH}$ of $8 \cdot 2-8 \cdot 3$ ) derived from the physico-chemical nature of seawater, both of which affect the way of life of organisms inhabiting such

Published online ahead of print on 1 November 2002 as DOI 10.1099/ ijs.0.02446-0.

The DDBJ accession numbers for the $16 \mathrm{~S}$ rRNA gene sequences of strains M13-2', M13-3, M13-4, M13-5, M13-6, M13-7, O1-1, O21 and Carnobacterium mobile DSM $4848^{\top}$ are AB083406, AB083407, AB083408, AB083409, AB083410, AB083411, AB083412, $\mathrm{AB} 083413$ and $\mathrm{AB} 083414$, respectively. conditions. The sea, especially in coastal areas, is abundant in biota, dead or living, which are rich sources of nutrients necessary for the growth of heterotrophic micro-organisms. Many ecological and taxonomic studies on marine bacteria have been carried out, but most have been concerned with aerobic or facultatively anaerobic, Gram-negative bacteria. Isolation and taxonomic studies of lactic acid bacteria from marine environments to date are few and have generally been confined to those from cultured fish (Ringø \& Gatesoupe, 1998; Gatesoupe, 1999). Franzmann et al. (1991) isolated two species of lactic acid bacteria, Carnobacterium funditum and Carnobacterium alterfunditum, from the water of Ace Lake in Antarctica of possible seawater origin (Masuda et al., 1988). 
In this paper, we describe the isolation (from dead or living marine organisms), taxonomic characterization and phylogenetic position of a novel halophilic and alkaliphilic lactic acid bacterium, for which the name Marinilactibacillus psychrotolerans gen. nov., sp. nov. is proposed. We show further that the obligately alkaliphilic Alkalibacterium olivoapovliticus (Ntougias \& Russell, 2001), corrected on notification to Alkalibacterium olivapovliticus (International Committee on Systematics of Prokaryotes, 2001), the closest phylogenetic neighbour of the new isolates, is a member of the lactic acid bacteria.

\section{METHODS}

Samples for isolation of lactic acid bacteria. The samples for the isolation of lactic acid bacteria were collected from Oura beach, Miura Peninsula, Kanagawa Prefecture, in the middle of the Japanese mainland, a temperate area, in July 1998, and from a foreshore site near the Oujima Islet and a fish market in the city of Naha, both in Okinawa in the Southernmost part of Japan, a subtropical area, in September 1998. The collected samples were living, fresh or decomposing sponges, algae, shellfish, crabs and fish.

Isolation media. For the samples collected from the Miura Peninsula, a $7 \% \mathrm{NaCl}$ GYPB isolation broth was used for the enrichment culture in the isolation procedure. It was composed of $10 \mathrm{~g}$ glucose, $5 \mathrm{~g}$ yeast extract (Oriental Yeast), $5 \mathrm{~g}$ Polypeptone (Nippon Seiyaku), $5 \mathrm{~g}$ beef extract (Difco), $1 \mathrm{~g} \mathrm{~K}_{2} \mathrm{HPO}_{4}, 70 \mathrm{~g} \mathrm{NaCl}$, $10 \mathrm{~g}$ sodium acetate, $0.5 \mathrm{~g}$ Tween $80,10 \mathrm{mg}$ cycloheximide, $10 \mathrm{mg}$ colistin, $15 \mathrm{mg}$ nalidixic acid, $20 \mathrm{mg}$ monofluoroacetic acid, $10 \mathrm{mg}$ sodium azide, $15 \mathrm{~g} \mathrm{Na}_{2} \mathrm{CO}_{3}$ (as a buffer) and $10 \%(\mathrm{w} / \mathrm{v})$ seawater to $1000 \mathrm{ml}$. The final $\mathrm{pH}$ was $10 \cdot 0$. The medium was sterilized by filtration through a membrane filter with a $0 \cdot 2 \mu \mathrm{m}$ pore size (Toyo Roshi Kaisha). The pour-plating medium was $7 \% \mathrm{NaCl}$ GYPB isolation agar ( $1 \cdot 3 \%$ agar) supplemented with $5 \mathrm{~g} \mathrm{CaCO} \cdot \mathrm{Ca}_{2} \mathrm{CO}_{3}$ and $\mathrm{CaCO}_{3}$ were autoclaved separately at $121{ }^{\circ} \mathrm{C}$ for $15 \mathrm{~min}$ and added aseptically (final $\mathrm{pH}, 10 \cdot 0$ ). The agar medium for overlaying on the pour plates contained $0 \cdot 1 \%(\mathrm{w} / \mathrm{v})$ sodium thioglycolate and the inorganic ingredients of the $7 \% \mathrm{NaCl}$ GYPB isolation broth. For the samples collected from Okinawa, two series of media were used for enrichment. One medium, the $7 \% \mathrm{NaCl}$ GYPF isolation broth, was the same as the $7 \% \mathrm{NaCl}$ GYPB isolation broth but with Extract Bonito (Wako Pure Chemical Industries) instead of beef extract, with sodium acetate and Tween 80 omitted, and with $5 \mathrm{ml}$ of a salts solution added, and prepared with distilled water to $1000 \mathrm{ml}, \mathrm{pH} \mathrm{7 \cdot 5}$. The medium was sterilized by filtration. The salt solution was composed of $\left(\mathrm{ml}^{-1}\right): 40 \mathrm{mg} \mathrm{MgSO}_{4} \cdot 7 \mathrm{H}_{2} \mathrm{O}, 2 \mathrm{mg}$ $\mathrm{MnSO}_{4} \cdot 4 \mathrm{H}_{2} \mathrm{O}$ and $2 \mathrm{mg} \mathrm{FeSO} \cdot 7 \mathrm{H}_{2} \mathrm{O}$ (Okada et al., 1992). For pour-plating, the $7 \% \mathrm{NaCl}$ GYPF isolation agar ( $1.3 \%$ agar) supplemented with $5 \mathrm{~g} \mathrm{CaCO}_{3} \mathrm{l}^{-1}$ was used. The overlaying agar medium contained $0 \cdot 1 \%(\mathrm{w} / \mathrm{v})$ sodium thioglycolate and the inorganic ingredients of the $7 \% \mathrm{NaCl}$ GYPF isolation broth. The other media for the enrichment were 12 and $18 \%$ (for a subsequent second enrichment) $\mathrm{NaCl}$ GYPFSK isolation broths, which consisted of $10 \mathrm{~g}$ glucose, 5 g yeast extract, $5 \mathrm{~g}$ Polypeptone, $5 \mathrm{~g}$ Extract Bonito, $50 \mathrm{ml}$ soy sauce, $10 \mathrm{~g} \mathrm{~K}_{2} \mathrm{HPO}_{4}, 110 / 170 \mathrm{~g} \mathrm{NaCl}, 1 \mathrm{~g}$ sodium thioglycolate, $5 \mathrm{ml}$ salts solution, $10 \mathrm{mg}$ cycloheximide and distilled water to $1000 \mathrm{ml}$. The medium was adjusted to $\mathrm{pH} 7 \cdot 5$ and autoclaved at $110{ }^{\circ} \mathrm{C}$ for $10 \mathrm{~min}$. For pour-plating, the $12 \% \mathrm{NaCl}$ GYPFSK isolation agar $(2 \cdot 0 \%$ agar, final $\mathrm{pH} 7 \cdot 5)$ supplemented with $5 \mathrm{~g} \mathrm{CaCO}_{3} \mathrm{l}^{-1}$ was used.

Isolation procedure and strains for study. For enrichment with the $7 \% \mathrm{NaCl}$ GYPB isolation broth (Miura Peninsula samples) or the $7 \% \mathrm{NaCl}$ GYPF isolation broth (Okinawa samples), small pieces of the samples (intestinal contents or whole bodies for animal samples) were soaked in $5 \mathrm{ml}$ enrichment medium immediately after collection. After incubation at $30^{\circ} \mathrm{C}$ for 3 days, a portion of the enrichment culture broth, whose $\mathrm{pH}$ had decreased to below $7 \cdot 0$, was put into fresh medium and incubated anaerobically at $30^{\circ} \mathrm{C}$ for 2 days. A portion of the second enrichment culture broth was pourplated and a plate was overlaid with the overlaying agar medium. In another isolation series of the Okinawa samples, the $12 \% \mathrm{NaCl}$ GYPFSK isolation broth was used for a first enrichment incubated for 21 days, and the $18 \% \mathrm{NaCl}$ GYPFSK isolation broth was used for a second enrichment incubated for 15 days, both at $25^{\circ} \mathrm{C}$ in standing culture. Pour-plated agar media were not overlaid. Lenticular colonies were picked up and the isolates were purified with repeated pour-plating. Six isolates, M13-2 ${ }^{\mathrm{T}}, \mathrm{M} 13-3, \mathrm{M} 13-4$, M13-5, M13-6 and M13-7, were obtained from a living sponge from the Miura Peninsula. One isolate, O1-1, was from a raw Japanese ivory shell (Babylonia japonica) cultured with the $7 \% \mathrm{NaCl}$ GYPF isolation broth enrichment, and another isolate, O21, was from a decomposing alga cultured with the $12-18 \% \mathrm{NaCl}$ GYPFSK isolation broth enrichment. Both samples were collected from Okinawa. Alkalibacterium olivapovliticus NCIMB $13710^{\mathrm{T}}$, Carnobacterium divergens IFO $15683^{\mathrm{T}}$ and Carnobacterium mobile DSM $4848^{\mathrm{T}}$ were used as reference strains. These were obtained from the National Collections of Industrial, Food and Marine Bacteria (NCIMB), Aberdeen, UK, the Institute for Fermentation, Osaka (IFO), Osaka, Japan and Deutsche Sammlung von Mikroorganismen und Zellkulturen GmbH (DSMZ), Braunschweig, Germany, respectively.

Media and conditions for cultivation and taxonomic characterization. Unless otherwise stated, a $2 \cdot 5 \% \mathrm{NaCl}$ GYPF broth, composed of $10 \mathrm{~g}$ glucose, $5 \mathrm{~g}$ yeast extract, $5 \mathrm{~g}$ Polypeptone, $5 \mathrm{~g}$ Extract Bonito, $1 \mathrm{~g} \mathrm{~K}_{2} \mathrm{HPO}_{4}, 25 \mathrm{~g} \mathrm{NaCl}, 1 \mathrm{~g}$ sodium thioglycolate, $5 \mathrm{ml}$ salt solution and distilled water to $1000 \mathrm{ml}$, was used as the basal medium for cultivation and taxonomic characterization. The medium was adjusted to $\mathrm{pH} 8.5$ and sterilized by filtration. In some experiments, a $2.5 \% \mathrm{NaCl}$ GYPF broth with the concentration of $\mathrm{K}_{2} \mathrm{HPO}_{4}$ raised to $1 \%$ was used to improve growth by buffering the medium $(2.5 \% \mathrm{NaCl}$ GYPFK broth). The medium used for the maintenance of cultures was prepared with $7 \% \mathrm{NaCl}$ GYPF isolation agar by adding $12 \mathrm{~g} \mathrm{Na}_{2} \mathrm{CO}_{3}$ and $3 \mathrm{~g} \mathrm{NaHCO}_{3} \mathrm{l}^{-1}$, omitting selective agents, and supplementing with $\mathrm{CaCO}_{3}$. Main components, buffer compounds and $\mathrm{CaCO}_{3}$ were sterilized separately. The final $\mathrm{pH}$ was $9 \cdot 0$. The isolates were stored at $5{ }^{\circ} \mathrm{C}$ and transferred at 1-month intervals.

Cultivation was at $30^{\circ} \mathrm{C}$ unless otherwise stated. Anaerobic cultivation was conducted by absorbing the oxygen in a container for test tube cultures with AnaeroPack-Kenki ( $\mathrm{CO}_{2}$-generated; Mitsubishi Gas Chemical). Alkalibacterium olivapovliticus NCIMB $13710^{\mathrm{T}}$ was cultivated and maintained in the same way as the new isolates. Carnobacterium divergens IFO $15683^{\mathrm{T}}$ and Carnobacterium mobile DSM $4848^{\mathrm{T}}$ were cultivated according to the usual methods.

Cultural and morphological characteristics. Cellular morphology was observed for unstained cells mounted on a $2 \%$ water agar film with phase-contrast microscopy. Cultural characteristics of colonies were observed with $2 \cdot 5 \% \mathrm{NaCl}$ GYPF agar ( $1.3 \%$ agar). Motility was examined microscopically for cells cultured in $2.5 \%$ $\mathrm{NaCl}$ GYPFK broth and by observing the occurrence of diffused growth along the stab line in semi-solid $2 \cdot 5 \%$ GYPFK agar $(0 \cdot 15 \%$ agar). These two agar media were sterilized by autoclaving at $110^{\circ} \mathrm{C}$ for $10 \mathrm{~min}$. Gram staining was carried out by using a crystal violet/ phenol solution (Merck) following the procedure as described by Murray et al. (1994). Spore formation was examined microscopically. Flagellation was observed in cells grown on $2.5 \% \mathrm{NaCl}$ GYPF 
agar incubated anaerobically and stained by the method of Nishizawa \& Sugawara as described by the Alumni Association of The Institute of Medical Sciences, The University of Tokyo (1988).

Physiological and biochemical characteristics. The catalase and oxidase reactions were tested with cells grown in $2.5 \% \mathrm{NaCl}$ GYPF broth. The oxidase activity was examined with an oxidase test strip (Eiken Chemical). To observe behaviour against oxygen concentration, $2.5 \% \mathrm{NaCl}$ GYPFK soft agar $(0.6 \%$ agar $)$ in a tube was evenly inoculated with a portion of appropriately diluted young broth culture by mixing, and the density and size of the colonies that grew were observed. For the sugar fermentation tests, sugars were added to $2.5 \% \mathrm{NaCl}$ GYPF broth without glucose in $1 \%$ concentrations and filter-sterilized. For the starch and inulin tests, the media were sterilized at $110{ }^{\circ} \mathrm{C}$ for $10 \mathrm{~min}$. Production of acid was scored as positive when the titre of $0 \cdot 1 \mathrm{M} \mathrm{NaOH}$ per $5 \mathrm{ml}$ cultured broth was $\geqslant 0.25 \mathrm{ml}$ and as weakly positive when it was $\geqslant 0.05 \mathrm{ml}$ and $<0.25 \mathrm{ml}$. The catalase reaction, nitrate reduction, production of gas from glucose, production of ammonia from arginine, and gelatin (Difco; $2 \%, \mathrm{w} / \mathrm{v})$ liquefaction tests were conducted by following Okada et al. (1992), using medium supplemented with $2.5 \%$ $\mathrm{NaCl}$ and adjusted to $\mathrm{pH} 8 \cdot 5$, or $2 \cdot 5 \% \mathrm{NaCl}$ GYPF medium.

Growth characteristics in relation to $\mathrm{NaCl}$ concentration, pH and temperature. The optimum $\mathrm{NaCl}$ concentration and range for growth were investigated with $2 \cdot 5 \% \mathrm{NaCl}$ GYPF broth prepared with $\mathrm{NaCl}$ concentrations from 0 to $3.0 \%(\mathrm{w} / \mathrm{v})$ at $0.5 \%$ intervals, $3.75 \%, 5.0 \%$ and from 18.5 to $21.0 \%$ at $0.5 \%$ intervals. To determine maximum and minimum concentrations, growth during 7 days of observation was scored as positive when the titre of $0 \cdot 1 \mathrm{M}$ $\mathrm{NaOH}$ per $5 \mathrm{ml}$ cultured broth was $\geqslant 0.25 \mathrm{ml}$ and simultaneously, $\mathrm{OD}_{660}$ was $\geqslant 0 \cdot 1$. The effect of temperature on growth was investigated by incubating at $-1.8{ }^{\circ} \mathrm{C}$, from 0 to $40^{\circ} \mathrm{C}$ at intervals of $5^{\circ} \mathrm{C}$, but with $37^{\circ} \mathrm{C}$ replacing $35^{\circ} \mathrm{C}$, and from 40 to $47.5^{\circ} \mathrm{C}$ at intervals of $2.5^{\circ} \mathrm{C}$. To determine maximum and minimum growth temperatures, growth was observed for 1 day to 3 weeks, depending on temperature, and scored as for the $\mathrm{NaCl}$ test. To study the effect of medium $\mathrm{pH}$ on growth, $\mathrm{pH}$ values of $2.5 \% \mathrm{NaCl}$ GYPF broth were adjusted from 5.5 to 11.5 at intervals of $0.5 \mathrm{pH}$ units. Maximum and minimum $\mathrm{pHs}$ were determined by measuring the $\mathrm{pH}$ of a noninoculated medium exactly when growth occurred in a cultured broth with the same initial $\mathrm{pH}$, because the $\mathrm{pH}$ of non-inoculated, alkaline medium gradually decreased during incubation. The occurrence of growth was judged by optical density as for the $\mathrm{NaCl}$ test. Growth optima for $\mathrm{NaCl}$ concentration, $\mathrm{pH}$ and temperature were determined by using the maximum specific growth rate, $\mu_{\max }\left(\mathrm{h}^{-1}\right)$, calculated from growth curves given by $\mathrm{OD}_{660}$.

Fermentation products. Fermentation products from glucose were analysed by HPLC for broth cultured for 4 days, and then centrifuged and filtered through an ultrafree-MC tube $(0.2 \mu \mathrm{m}$ pore size; Millipore) to remove cells. Organic acids were analysed by using an LC-10A HPLC system (Shimadzu) with a Shim-pack SCR$102 \mathrm{~N}$ column (Shimadzu) or a Shodex OA HPLC system (Shodex) with a Shodex Ionpak KC-811. The amount of ethanol produced was estimated by using an LC-9A HPLC system (Shimadzu) with a Shim-pack SCR-101N column (Shimadzu). The amount of glucose was determined by the Somogyi method (Somogyi, 1945) or enzymically by using glucose oxidase (Wako Pure Chemical Industries). The isomeric forms of lactic acid produced were determined enzymically by using D- and L-lactic acid dehydrogenases (Roche Diagnostics).

Analysis of fermentation products formed at different pHs. Cultivation was performed in buffered $2.5 \% \mathrm{NaCl}$ GYPF broth supplemented with $100 \mathrm{mM}$ HEPPS and adjusted to different $\mathrm{pH}$ values. The $\mathrm{pH}$ was $7 \cdot 0,8 \cdot 0$ or $9 \cdot 0$ for strains $\mathrm{M} 13-2^{\mathrm{T}}$ and $\mathrm{O} 21$, and $8 \cdot 0,9 \cdot 0$ or $10 \cdot 0$ for Alkalibacterium olivapovliticus NCIMB $13710^{\mathrm{T}}$.
The analysis of fermentation products was conducted for cultured broth whose $\mathrm{OD}_{660}$ had reached about $0 \cdot 20$ to minimize the effect of any decrease in $\mathrm{pH}$ during fermentation. Products were analysed by the same method as described above.

Fatty acid analysis. Cells were cultivated in $2.5 \% \mathrm{NaCl}$ GYPFK broth. The freeze-dried cells were hydrolysed with $4 \mathrm{M} \mathrm{HCl}$ at $100{ }^{\circ} \mathrm{C}$ for $5 \mathrm{~h}$ (Kawahara et al., 1979). The resultant fatty acids were extracted and methylated with a $5 \% \mathrm{HCl} /$ methanol mixture at $100{ }^{\circ} \mathrm{C}$ for $3 \mathrm{~h}$ (Suto et al., 1982). The fatty acid analysis was carried out according to the procedure as described by Goto et al. (2002). GC-MS was performed with a Hewlett Packard HP 5890 gas chromatograph equipped with a type DB-23 capillary column (J \& B Scientific) and DX-303 and DA-5000 mass spectrometers (JEOL). The column temperature was programmed to increase from 50 to $130{ }^{\circ} \mathrm{C}$ at a rate of $70{ }^{\circ} \mathrm{C} \mathrm{min}{ }^{-1}$ and from 130 to $210^{\circ} \mathrm{C}$ at a rate of $3{ }^{\circ} \mathrm{C} \mathrm{min}{ }^{-1}$. Fatty acid methyl esters were identified by comparing mass spectra and retention times with fatty acid methyl ester standards (Sigma or Supelco).

Detection of respiratory quinone. The lipid fraction was extracted from cells harvested from $2 \cdot 5 \% \mathrm{NaCl}$ GYPFK broth culture and freeze-dried as described by Sano et al. (1996). The presence of respiratory quinone was examined by TLC as described by Yamada \& Kuraishi (1982).

Amino acid composition of the cell wall. Cells were cultivated in $2.5 \% \mathrm{NaCl}$ GYPFK broth. The presence of diaminopimelic acid was examined by TLC by following the method of Hasegawa et al. (1983) as described by Okada et al. (1992). Peptidoglycan and its hydrolysate were prepared by the method of Komagata \& Suzuki (1987). The amino acid composition was determined by using an LC-6A HPLC system (Shimadzu) with a Shim-pack Amino-Na ion exchange column (Shimadzu).

Determination of DNA base composition and DNA relatedness. To determine the DNA base composition and DNA relatedness, DNA was extracted and purified by following the combined methods of Marmur (1961) and Saito \& Miura (1963). DNA base composition was determined by reverse-phase HPLC (Tamaoka \& Komagata, 1984). DNA relatedness was estimated by the fluorometric DNA-DNA hybridization method in microdilution wells as described by Ezaki et al. (1989).

$16 S$ rRNA gene sequence determination. Cells were cultivated in $2.5 \% \mathrm{NaCl}$ GYPFK broth. DNA was extracted and purified as described above. Gene fragments specific for the 16S rRNA-coding regions of the isolates were amplified by PCR with the following two primers: 20F (5'-AGTTTGATCATGGCTCA-3', positions 10-26) and 1540R (5'-AAGGAGGTGATCCAACCGCA-3', positions 15411521) (Escherichia coli numbering system; Brosius et al., 1978) as described by Yanagi \& Yamasato (1993). The amplified 16S rRNA gene was sequenced directly by using an ABI PRISM BigDye Terminator Cycle Sequencing Ready Reaction kit and an ABI PRISM model 310 genetic analyser (Perkin-Elmer). The following five primers were used: 20F, 1540R, 350F ( $5^{\prime}$-CCTACGGGAGGCAGCAGT3', positions 341-358), 800F (5'-GTAGTCCACGCCGTAAACGA-3', positions 803-819) and 900R (5'-CGGCCGTACTCCCCAGGCGG3', positions 898-879).

Phylogenetic analysis. Multiple alignment was performed by using the program CLUSTAL X (version 1.8; Thompson et al., 1997). Percentage similarities among the new isolates and related organisms were calculated in pairs of homologous sequences of 1422-1468 bases. Phylogenetic distances $\left(K_{\text {nuc }}\right)$ for the aligned sequences were calculated by using the 2-parameter method of Kimura (1980). The neighbourjoining method (Saitou \& Nei, 1987) was used for constructing a phylogenetic tree. Hypervariable regions at positions 66-103 (including V1 region) and 1436-1457 (V5 region) were omitted from the 


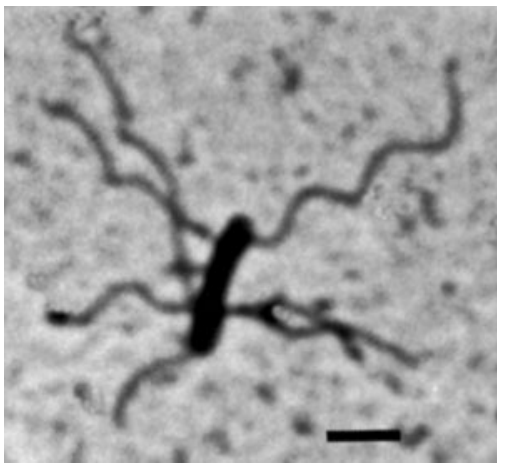

Fig. 1. Photomicrograph of cells and peritrichous flagella of Marinilactibacillus psychrotolerans $\mathrm{M} 13-2^{\top}$ grown anaerobically at $30{ }^{\circ} \mathrm{C}$ for 2 days on $2.5 \% \mathrm{NaCl}$ GYPFK agar. Bar, $2 \mu \mathrm{m}$.

phylogenetic analysis. The topology of the phylogenetic tree was evaluated by bootstrapping with 1000 replications (Felsenstein, 1985). Nucleotide sequences of the new isolates were deposited in the DNA Database of Japan (DDBJ). Accession numbers of the isolates deposited and the reference strains from the public databases are shown in Fig. 2.

\section{RESULTS AND DISCUSSION}

\section{General taxonomic features}

All eight newly isolated strains exhibited similar taxonomic features. The isolates were Gram-positive rods that were motile with peritrichous flagella (Fig. 1). Spores were not produced. Catalase was not produced by the cells cultivated in $2.5 \% \mathrm{NaCl}$ GYPF broth or in the medium with glucose concentration reduced to $0 \cdot 1 \%$. Growth was weak when the glucose concentration in $2.5 \% \mathrm{NaCl}$ GYPFK broth was reduced to $0 \cdot 1 \%$, and no growth was seen when glucose was omitted. The isolates were able to grow, but with little vigour, on a $2 \cdot 5 \% \mathrm{NaCl}$ GYPFK agar plate exposed to air. The density and size of colonies developed in semi-solid medium, evenly inoculated and incubated while exposed to air, was uniform from the surface to the bottom, and not affected by the oxygen concentration of the medium. A fairly wide range of carbohydrates, sugar alcohols and related carbon compounds was fermented with some variations among the isolates (Table 1). Cultural, morphological, physiological and biochemical features other than those described above are presented below and in the descriptions of the new genus and the new species.

\section{Lactic acid fermentation and effect of cultivation pH on product composition}

The end products of glucose fermentation by the different isolates were determined. Lactate was produced with yields, depending on isolates, of 87 to $100 \%$ relative to the amount of consumed glucose, without gas production. The ratio of the $\mathrm{L}(+)$ isomer to total lactate produced was $75: 94 \%$. Besides lactate, trace to small amounts of formate, acetate and ethanol were produced with a molar ratio of approximately $2: 1: 1$.

The $\mathrm{pH}$ of the fermented medium had a large effect on the relative amount of lactate versus the other three products. For representative selected strains of $\mathrm{M} 13-2^{\mathrm{T}}$ and $\mathrm{O} 21$, fermentation products from glucose obtained by using buffered media are shown in Table 2. During the course of

Table 1. Sugar fermentation profiles of the eight new isolates

Fermentation is scored as: +, positive; -, negative; or W, weakly positive. All eight strains fermented D-ribose, D-xylose, D-fructose, D-glucose, D-mannose, D-cellobiose, maltose, sucrose, D-trehalose, D-mannitol, $\alpha$-methyl-D-glucoside, D-salicin and sodium gluconate, but did not ferment myo-inositol.

\begin{tabular}{|lcccccccc|}
\hline Carbon compound & \multicolumn{7}{c}{ Strain } \\
\cline { 2 - 9 } & M13-2 & M13-3 & M13-4 & M13-5 & M13-6 & M13-7 & O1-1 & O21 \\
\hline L-Arabinose & + & + & + & + & + & + & W & W \\
D-Arabinose & W & W & - & - & W & W & - & - \\
D-Galactose & + & + & + & + & + & + & + & - \\
D-Rhamnose & + & + & + & + & + & + & - & - \\
Lactose & W & W & W & W & W & W & + & + \\
Melibiose & + & - & + & - & - & - & - & - \\
D-Raffinose & - & - & + & - & - & - & + & W \\
D-Melezitose & - & - & + & - & - & - & - & W \\
Glycerol & W & W & W & W & W & W & + & + \\
Adonitol & - & - & - & - & - & - & - & W \\
Dulcitol & - & - & - & - & - & - & W & W \\
D-Sorbitol & - & - & - & - & - & - & + & W \\
Inulin & + & - & + & - & - & - & - & - \\
Starch & + & - & - & - & - & - & - & - \\
\hline
\end{tabular}


Table 2. Effect of $\mathrm{pH}$ on the balance of glucose fermentation by representative strains $\mathrm{M} 13-2^{\top}$ and $\mathrm{O} 21$, and $A / k a l i b a c t e r i u m$ olivapovliticus NCIMB $13710^{\top}$

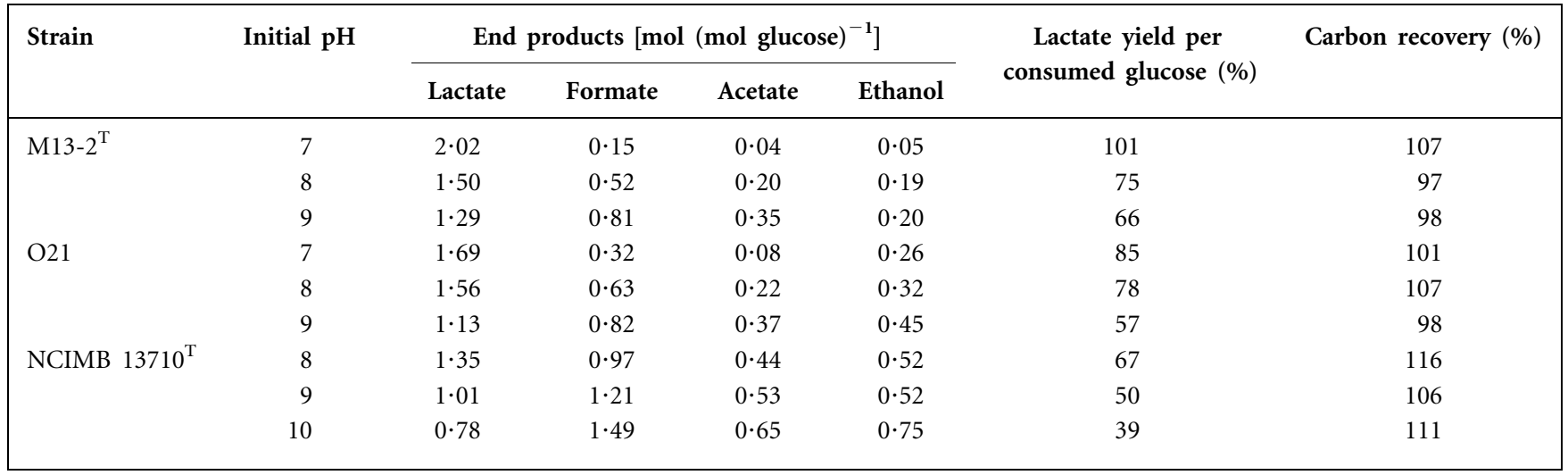

fermentation, a decrease in $\mathrm{pH}$ of $0 \cdot 3-0 \cdot 5 \mathrm{pH}$ units was observed for each of the initial cultivation $\mathrm{pHs}$. As the initial acidity of the media increased, the proportion of lactate also increased, while, in parallel, those of the other three products decreased, and vice versa on the alkaline side. For each initial cultivation $\mathrm{pH}$ value, carbon recovery of fermentation products against glucose consumed was approximately $100 \%$ and the molar ratios among the three products other than lactate were retained.

An analysis of the fermentation products of Alkalibacterium olivapovliticus NCIMB $13710^{\mathrm{T}}$ was also conducted and it was found to be a lactic acid bacterium as well, producing mainly lactic acid without gas formation (Table 2). The ratio of the $\mathrm{L}(+)$ isomer to total lactate produced was $41 \%$. Essentially, the same inverse relationship between the proportion of lactate produced and the proportion of the total amount of the other three products, with the molar ratio among them retained, that was exhibited by the new isolates was also observed for Alkalibacterium olivapovliticus NCIMB $13710^{\mathrm{T}}$ (Table 2).

Lactic acid fermentation accompanied by the production of these three products has been reported previously in Streptococcus liquefaciens (Gunsalus \& Niven, 1942), Streptococcus faecalis (Lindmark et al., 1969), Streptococcus mutans and Streptococcus sanguis (Carlsson \& Griffith, 1974), Streptococcus lactis (Thomas et al., 1979), Lactobacillus bulgaricus (Rhee \& Pack, 1980), Carnobacterium funditum and Carnobacterium alterfunditum (Franzmann et al., 1991) and Lactosphaera pasteurii (Janssen et al., 1995). In Streptococcus lactis (now Lactococcus lactis subsp. lactis) glucose-limited cultivation caused the proportions of formate, acetate and ethanol to increase (Thomas et al., 1979). In Lactobacillus bulgaricus (now Lactobacillus delbrueckii subsp. bulgaricus), fermentation media with an alkaline $\mathrm{pH}$ resulted in an increase in the relative amounts of these three products (Rhee \& Pack, 1980). The conversion of pyruvate at the end of the Embden-Meyerhof pathway can follow one of two pathways: the formation of lactate mediated by lactate dehydrogenase, or the formation of formate, acetate and ethanol mediated by pyruvate formate-lyase (Axelsson, 1993). In Streptococcus mutans, lactate dehydrogenase is activated by fructose 1,6-diphosphate (Carlsson \& Griffith, 1974; Yamada \& Carlsson, 1975) and pyruvate formate-lyase is inhibited by triose-phosphate (Takahashi et al., 1982). The decrease in the proportion of lactate produced under glucose-limited conditions was explained by the limited production of these intermediates which caused the reduced activity of lactate dehydrogenase and the retained activity of pyruvate formate-lyase. Although not examined enzymically, the isolates and Alkalibacterium olivapovliticus are assumed to have these two pyruvate pathways as well, and the pathway used would be affected by the $\mathrm{pH}$ value of the fermentation medium.

\section{Growth behaviour for $\mathrm{NaCl}, \mathrm{pH}$ and temperature}

The optimum $\mathrm{NaCl}$ concentration for growth was between $2 \cdot 0 \%(0 \cdot 34 \mathrm{M})$ and $3 \cdot 75 \%(0 \cdot 64 \mathrm{M})(3 \cdot 0-5 \cdot 0 \%$ for strain $\left.\mathrm{M} 13-2^{\mathrm{T}}\right)$. For strain M13-2 ${ }^{\mathrm{T}}$, the maximum specific growth rates, $\mu_{\max }\left(\mathrm{h}^{-1}\right)$, were 0.38 in $0 \%, 0.36$ in $0.5 \%, 0.40$ in $1.0 \%, 0.42$ in $1.5,2.0$ and $2.5 \%, 0.47$ in $3.0 \%, 0.51$ in $3 \cdot 75 \%, 0 \cdot 46$ in $5 \cdot 0 \%$ and 0.36 in $7 \cdot 5 \% \mathrm{NaCl}$. For strain M13-6, as another example, the values were 0.40 in 0 and $0.5 \%, 0.42$ in $1.0,1.5$ and $2.0 \%, 0.40$ in $2.5 \%, 0.60$ in $3.0 \%, 0.52$ in $3.75 \%, 0.44$ in $5.0 \%$ and 0.38 in $7.5 \% \mathrm{NaCl}$. Growth occurred in $2.5 \% \mathrm{NaCl}$ GYPF broth without $\mathrm{NaCl}$ and in those with $\mathrm{NaCl}$ concentrations from $17 \cdot 0$ to $20 \cdot 5 \%(2 \cdot 91-3 \cdot 51 \mathrm{M})$. The isolates were slightly halophilic (Kushner, 1978; Kushner \& Kamekura, 1988) and highly halotolerant. The only previously reported lactic acid rods which grow optimally at a salinity above $0 \%$ are Carnobacterium funditum and Carnobacterium alterfunditum: $1 \cdot 7$ and $0 \cdot 6 \%$, respectively (Franzmann et al., 1991). These species were isolated from the water of Ace Lake in Antarctica, which has a salinity of about 0.6 (bottom) to $4.3 \%$ (surface) (Burton, 1980) and has been suggested to be of seawater origin (Masuda et al., 1988). They grow optimally at low salinity, which suggests that they may have adapted to salt-containing environments.

The isolates are alkaliphilic (Jones et al., 1994). The initial optimum $\mathrm{pH}$ for growth was between $8 \cdot 0$ and $9 \cdot 5$. No 
growth was observed in media with an initial $\mathrm{pH} \leqslant 5 \cdot 5$ or $\geqslant 10 \cdot 5$. For strain $\mathrm{M} 13-2^{\mathrm{T}}$, the maximum specific growth rates, $\mu_{\max }\left(\mathrm{h}^{-1}\right)$, were $0 \cdot 44$ at $\mathrm{pH} 7 \cdot 0,0 \cdot 48$ at $\mathrm{pH} 7 \cdot 5,0 \cdot 53$ at $\mathrm{pH} 8 \cdot 0,0 \cdot 50$ at $\mathrm{pH} 8 \cdot 5,0 \cdot 51$ at $\mathrm{pH} 9 \cdot 0,0 \cdot 50$ at $\mathrm{pH} 9 \cdot 5$ and 0.34 at $\mathrm{pH} 10 \cdot 0$. However, the Carnobacterium species from the Antarctic lake are neutrophilic, growing best at $\mathrm{pH} 7 \cdot 0$. When the isolates were grown in $2 \cdot 5 \% \mathrm{NaCl}$ GYPF broth, $\mathrm{pH} 8 \cdot 5$, the final $\mathrm{pH}$ could be as low as $4 \cdot 7-5 \cdot 2$, which was 0.8 to $1.3 \mathrm{pH}$ units lower than the minimum $\mathrm{pH}$ required to initiate growth. It is noteworthy that our isolates preferred alkaline to acidic conditions and were unable to produce particularly acidic conditions as almost all terrestrial lactic acid bacteria are able to do as they prefer weakly acidic reactions and suppress other micro-organisms in their niches by making their surroundings acidic. However, the $\mathrm{pH}$ values of $4 \cdot 7-5 \cdot 2$ attained during the growth of the isolates may be sufficiently low to exclude other bacteria in seawater-associated, alkaline environments. The other alkaliphilic lactic acid bacteria reported so far are Pediococcus urinaeequi, which was described isolated from horse urine (Mees, 1934) and has an optimum $\mathrm{pH}$ of 9.0 or higher (Nakagawa \& Kitahara, 1959), and Alkalibacterium olivapovliticus, which was isolated from alkaline edible-olive wash waters $(\mathrm{pH} 10 \cdot 8)$ and has an optimum $\mathrm{pH}$ of $9 \cdot 0-10 \cdot 4$ (Ntougias \& Russell, 2001). Both organisms were isolated from terrestrial, alkaline environments. Our organisms were isolated from marine environments and are slightly halophilic and alkaliphilic, growing preferably under the physico-chemical conditions found in seawater. Thus, they are marine-inhabiting organisms and can be called 'marine lactic acid bacteria'.

The optimum temperature for growth of the isolates was $37-40^{\circ} \mathrm{C}$. The maximum specific growth rates, $\mu_{\max }\left(\mathrm{h}^{-1}\right)$, for strain $\mathrm{M} 13-2^{\mathrm{T}}$ were 0.36 at $25^{\circ} \mathrm{C}, 0.52$ at $30^{\circ} \mathrm{C}, 0.60$ at $37^{\circ} \mathrm{C}, 0.42$ at $40^{\circ} \mathrm{C}$ and 0.02 at $42.5^{\circ} \mathrm{C}$. The isolates grew under a wide range of temperatures from $-1.8^{\circ} \mathrm{C}$, the freezing point of seawater, to $40-45 \cdot 0{ }^{\circ} \mathrm{C}$. The optimum and maximum temperatures were markedly higher than those of usual marine bacteria. The isolates grew very well at lower temperatures with respect to the extent of maximum growth, although growth rates were low. For strain M13-2 ${ }^{\mathrm{T}}$, $\mathrm{OD}_{660}$ values were 0.78 at $-1.8^{\circ} \mathrm{C}(21$ days incubation $)$, 0.70 at $0{ }^{\circ} \mathrm{C}(21$ days $), 0.89$ at $5{ }^{\circ} \mathrm{C}(9$ days $)$ and 1.14 at $37^{\circ} \mathrm{C}$ ( $15 \mathrm{~h}$, the optimum temperature). For strain M13-5, they were 0.61 at $-1.8{ }^{\circ} \mathrm{C}$ (21 days), 0.85 at $0{ }^{\circ} \mathrm{C}$ (21 days), 0.98 at $5{ }^{\circ} \mathrm{C}(9$ days $)$ and 1.02 at $37^{\circ} \mathrm{C}(15 \mathrm{~h}$, the optimum temperature).

\section{Chemotaxonomic characteristics}

meso-Diaminopimelic acid was not associated with the cellwall peptidoglycans of the new isolates or Alkalibacterium olivapovliticus NCIMB $13710^{\mathrm{T}}$, as demonstrated by TLC. The purified cell wall of strain M13-2 $2^{\mathrm{T}}$ contained ornithine, glutamic acid and alanine in a molar ratio of $0 \cdot 8: 1: 1 \cdot 3$, and that of Alkalibacterium olivapovliticus NCIMB $13710^{\mathrm{T}}$ contained aspartic acid, ornithine, glutamic acid and alanine in a molar ratio of $0 \cdot 53: 1 \cdot 10: 1: 1 \cdot 82$. From these results, it was inferred that strain $\mathrm{M} 13-2^{\mathrm{T}}$ possessed peptidoglycan type A4 $\beta$, Orn-D-Glu, and that Alkalibacterium olivapovliticus NCIMB $13710^{\mathrm{T}}$ possessed peptidoglycan type A4 $\beta$, Orn-D-Asp. Our isolates also differed from those for other related genera: the diamino acid at position 3 is lysine in Dolosigranulum (type A4 $\alpha$, Lys-D-Asp) (Aguirre et al., 1993) and Desemzia (type A4 $\alpha$, Lys-D-Glu) (Stackebrandt et al., 1999), and meso-diaminopimelic acid in Carnobacterium (type Al $\gamma$, direct cross-linkage) (Collins et al., 1987; Franzmann et al., 1991). Among remotely related lactic acid rods, Lactobacillus fermentum and Lactobacillus pontis possess ornithine at position 3 (Williams \& Sadler, 1971; Vogel et al., 1994), but differ from our isolates by having aspartic acid as the cross-bridge amino acid.

The major cellular fatty acids of strain M13-2 ${ }^{\mathrm{T}}$ were characterized by straight-chain saturated and monounsaturated even-carbon-numbered types, with the composition $0 \cdot 4 \%$ C12:0; $5 \cdot 2 \%$ C14:0; $0 \cdot 4 \%$ C15:0; $32 \cdot 0 \%$ C16:0; $3 \cdot 1 \%$ $\mathrm{C} 16: 1 ; 19 \cdot 3 \% \mathrm{C} 16: 1 \Delta 9 ; 6 \cdot 9 \% \mathrm{C} 18: 0 ; 30 \cdot 2 \% \mathrm{C} 18: 1 \Delta 9$ (oleic acid); $1 \cdot 1 \% \mathrm{C} 18: 2$; and $1 \cdot 4 \% \mathrm{C} 20: 1$.

Respiratory quinones were not present in strain $\mathrm{M} 13-2^{\mathrm{T}}$.

\section{DNA base composition and DNA relatedness}

The $\mathrm{G}+\mathrm{C}$ contents of the DNAs of the eight new isolates fell in a narrow range from $34 \cdot 6$ to $36 \cdot 2 \mathrm{~mol} \%$. These isolates formed a single genomic species sharing $74-100 \%$ of DNA relatedness (Table 3), as was manifested by their possession of almost the same phenotypic features as shown above.

\section{5 rRNA gene sequence analysis}

Complete sequences of the $16 \mathrm{~S}$ rRNA gene, $1458-1479$ bases in length, were determined for the isolates. The sequences were aligned and compared with the sequences of 21 species of phylogenetically related bacteria and lactic acid bacteria from the public data libraries. The sequences of all eight isolates were identical over $1458 \mathrm{nt}$, covering the positions from 40 to 1487 (E. coli numbering system; Brosius et al., 1978). Comparison of almost complete sequences of the $16 \mathrm{~S}$ rRNA genes of the new isolates with homologous sequences from other related genera indicated that the isolates exhibited the highest similarity value to the genus Alkalibacterium (96.2\% similarity, $1459 \mathrm{nt}$ compared). The next highest similarity value was to strain $\mathrm{WN}-16$ (94.3\%), followed by Carnobacterium funditum (93.2\%) and other species of the genus Carnobacterium (92.1$92 \cdot 6 \%)$. Strain $\mathrm{WN}-16$ is an uncharacterized isolate from the alkaline littoral mud/water of Lake Nakuru in the Kenyan-Tanzanian Rift Valley (Duckworth et al., 1996). Sequence similarity values of the isolates to other genera were lower: Alloiococcus $(91 \cdot 1 \%)$, Dolosigranulum (90.9\%), Trichococcus (91.3-92.0\%) and Desemzia (91.9\%). A phylogenetic tree showed that the cluster of new isolates constituted an independent line of descent within the lactic acid bacteria group and placed it in a phylogenetic position most closely related to the genus Alkalibacterium (Fig. 2). 
Table 3. DNA base composition and DNA relatedness among the new isolates and related lactic acid rods

\begin{tabular}{|c|c|c|c|c|c|}
\hline Strain & $\begin{array}{l}\text { DNA base composition } \\
\qquad(\mathrm{mol} \% \mathrm{G}+\mathrm{C})\end{array}$ & \multicolumn{4}{|c|}{ Relative binding (\%) of DNA from: } \\
\hline M13-3 & $35 \cdot 7$ & 99 & & & \\
\hline M13-4 & $35 \cdot 7$ & 92 & & & \\
\hline M13-5 & $34 \cdot 6$ & 100 & & & \\
\hline O1-1 & $34 \cdot 7$ & 74 & 100 & 4 & \\
\hline $\mathrm{O} 21$ & $34 \cdot 6$ & 81 & & 3 & \\
\hline A. olivapovliticus NCIMB $13710^{\mathrm{T}}$ & $39 \cdot 7^{\star}$ & & & 100 & \\
\hline C. divergens $\mathrm{IFO} 15683^{\mathrm{T}}$ & $36 \cdot 4 \dagger$ & & & & 100 \\
\hline
\end{tabular}

${ }^{*}$ Data from Ntougias \& Russell (2001).

$\dagger$ Data from Collins et al. (1987).

The new isolates, the genera Alkalibacterium, Alloiococcus and Dolosigranulum, and strain WN-16 constituted a phylogenetic cluster with a high bootstrap value $(96 \cdot 7 \%)$. In the phylogenetic tree, the branching point between the lineage of the new isolates and the lineage composed of the genera Alloiococcus and Dolosigranulum was closer than the branching point between the lineage of the isolates and the species of the genus Carnobacterium, despite the higher sequence similarities to Carnobacterium species.

\section{5 rRNA secondary structure}

The predicted secondary structure of the V6 region of the $16 \mathrm{~S}$ rRNA of the new isolates was compared with those of other related genera (Ntougias \& Russell, 2001) and proved to be different from all of them (Fig. 3). The terminal ring in the V6 region of the isolates consisted of $10 \mathrm{nt}$, whereas corresponding rings of the genus Alkalibacterium and all other related genera were 2 or $3 \mathrm{nt}$ smaller. The pair of nucleotides at positions 462 and 471 are purine and pyrimidine nucleotides in all other related genera, whereas the nucleotides at these positions are both pyrimidines in our isolates and do not make a pair, resulting in the larger ring. The nucleotides of the isolates at positions 478 and 479 and at their complementary positions were the same as those of the genera Alkalibacterium and Desemzia, but differed from those of the genera Alloiococcus, Dolosigranulum and Carnobacterium. The V6 region of the isolates possessed the sequence UCGGGU at positions 457-462 and the complementary nucleotide sequence at positions $471-476$, which was not the case in the genus Alkalibacterium or in other related genera. This difference in the nucleotide sequences seems to be at the genus level, as they also differ among the genera Alkalibacterium, Alloiococcus, Dolosigranulum, Carnobacterium (identical for 7/7 species), Desemzia, Trichococcus (two types for four species), Vagococcus (identical for $3 / 4$ species) and Enterococcus (identical for $18 / 26$ species).

\section{Distinguishing features of the isolates}

With regard to phenotypic characteristics, the isolates were similar to the genus Alkalibacterium. No remarkable differences were found in cellular morphology, motility, halophilic property (Alkalibacterium has the an optimum at $3-5 \% \mathrm{NaCl}$ ) and salt tolerance (Alkalibacterium can grow in $15 \% \mathrm{NaCl}$ ), fermentation characteristics or the presence of oleic acid among their cellular fatty acids (Ntougias \& Russell, 2001). But the isolates could be clearly distinguished from the genus Alkalibacterium by the peptidoglycan type, the structure of the V6 region of the $16 \mathrm{~S}$ rRNA, the optimum and the range of $\mathrm{pH}$ for growth (Alkalibacterium is obligatory alkaliphilic with a minimum growth $\mathrm{pH}$ at 8.0 ) and the minimum growth temperature $\left(-1.8^{\circ} \mathrm{C}\right.$ versus $\left.5^{\circ} \mathrm{C}\right)$. The isolates could be distinguished from the closely neighbouring genera and homofermentative lactic acid rods. They were distinguishable from the genus Alloiococcus by cellular morphology, motility, catalase reaction, energy metabolism and DNA base composition (Alloiococcus are catalase-positive, non-motile cocci and do not ferment glucose, and the G $+\mathrm{C}$ content is $44-45 \mathrm{~mol} \%$ ); from the genus Dolosigranulum by cellular morphology and peptidoglycan type (Dolosigranulum has non-motile ovoid cells and lysine at position 3 of peptidoglycan); from the genus Desemzia by peptidoglycan type and cellular fatty acid composition (Desemzia has lysine at position 3 of peptidoglycan and cis-vaccenic acid in the fatty acid composition); from homofermentative Lactobacillus spp., depending on species, by motility, cellular fatty acid composition and DNA base composition; from the genus Carnobacterium by peptidoglycan type (peptidoglycan type of Carnobacterium is type A1 $\gamma$, direct cross-linkage); and from the genus Paralactobacillus by DNA base composition (DNA base composition of Paralactobacillus is $45-47 \mathrm{~mol} \%$ $\mathrm{G}+\mathrm{C})$. Except for the genus Alkalibacterium, and Carnobacterium funditum and Carnobacterium alterfunditum the isolates can be distinguished from the genera mentioned 


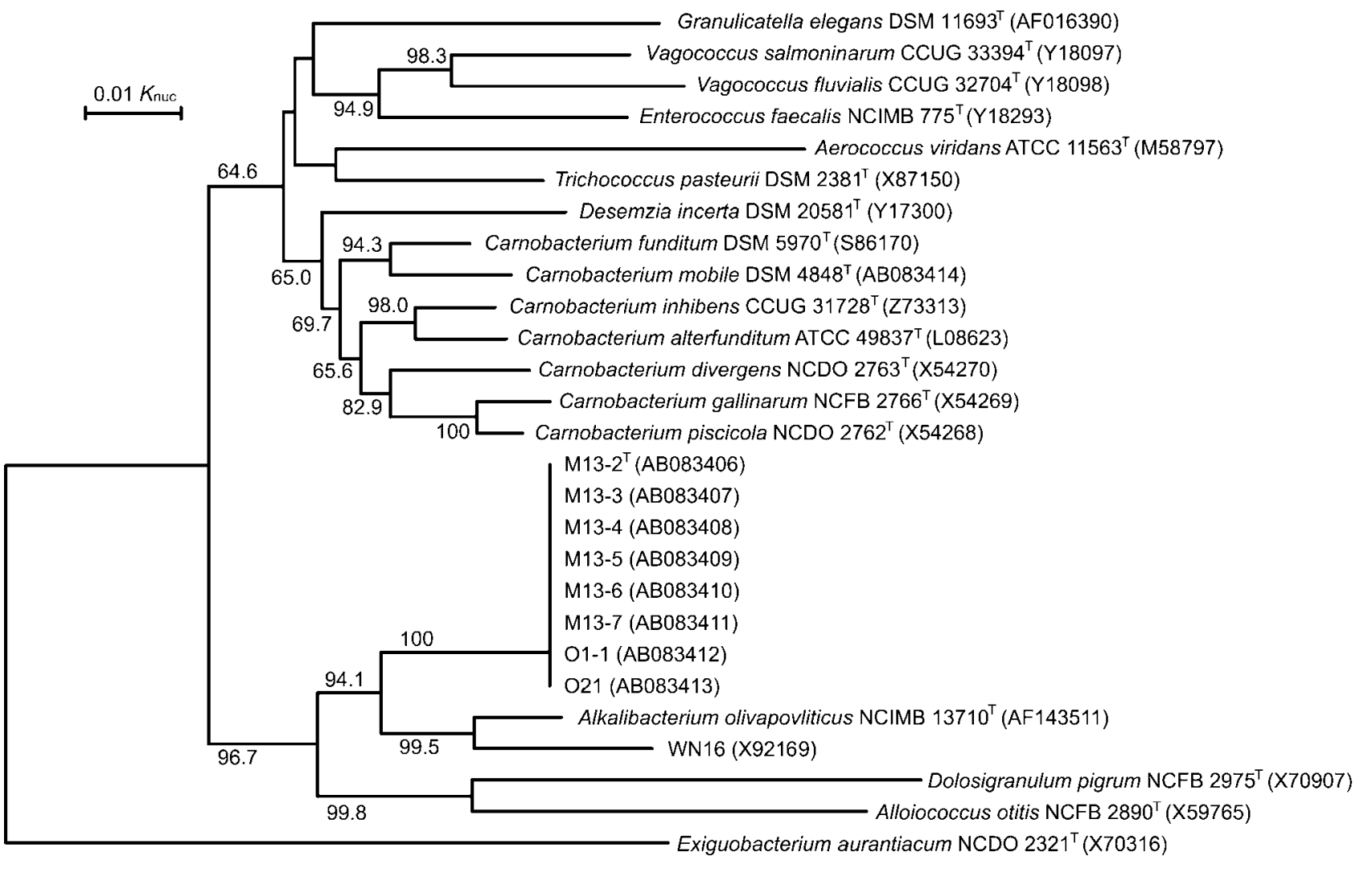

Fig. 2. Phylogenetic relationships between the new isolates and some other related bacteria belonging to the lactic acid group. Exiguobacterium aurantiacum NCDO $2321^{\top}$ was used as an outgroup. The tree, constructed using the neighbourjoining method, is based on a comparison of approximately $1390 \mathrm{nt}$. Bar, $0.01 K_{\text {nuc }}$ in nucleotide sequences. Bootstrap values, expressed as a percentage of 1000 replications, are given at branching points; only values above $50 \%$ are indicated.
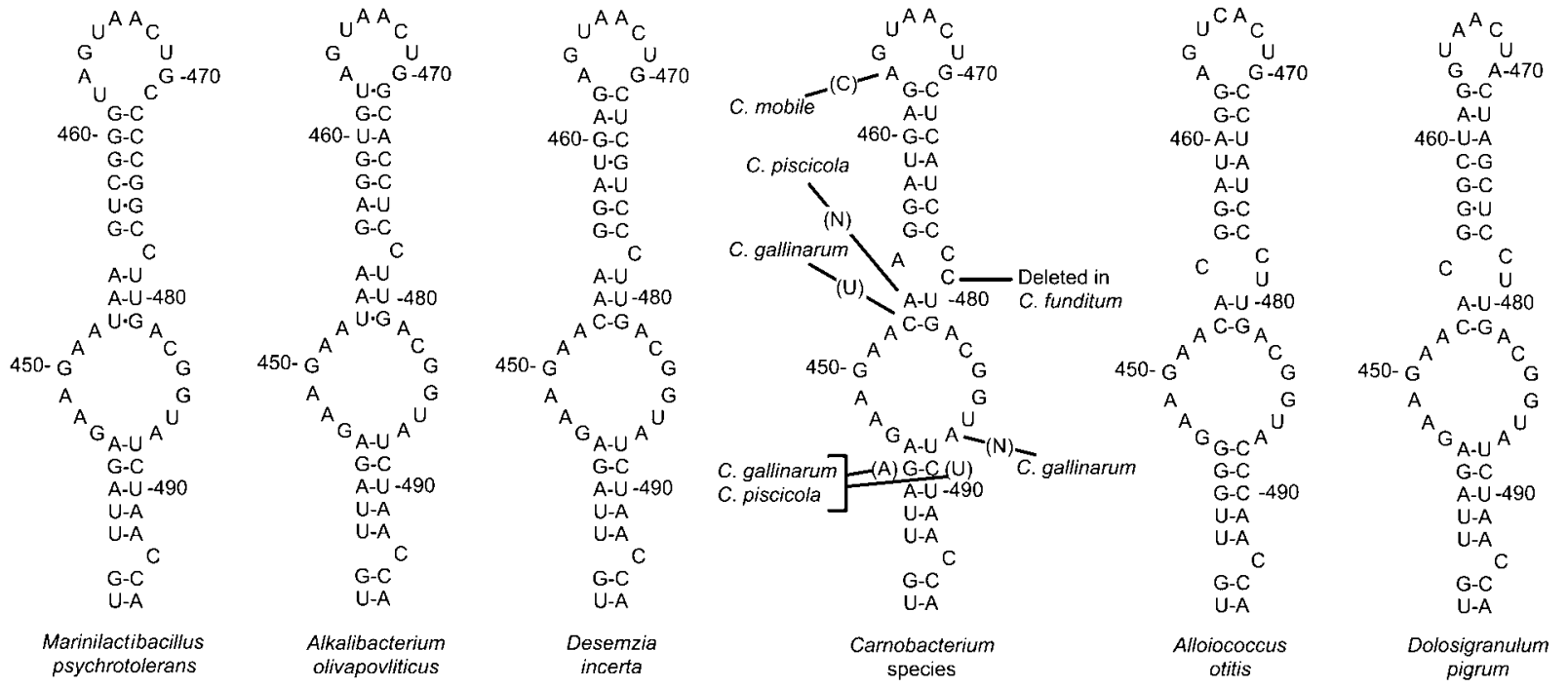

Fig. 3. Nucleotide sequences and secondary structures of the V6 region of the $16 \mathrm{~S}$ rRNA of the new isolates and closely related bacteria. Numbers correspond to positions in the $E$. coli sequence. 
above by all of the characteristics of halophilic and alkaliphilic properties, halotolerance, peptidoglycan type and the structure of the V6 region of the 16S rRNA.

In conclusion, on the basis of phenotypic features, chemotaxonomic characteristics, phylogenetic relationships and the secondary structure and nucleotide sequence of the V6 region of the $16 \mathrm{~S}$ rRNA, our isolates should be classified as a new genus and species. For the organism we propose the name Marinilactibacillus psychrotolerans gen. nov., sp. nov.

\section{Description of Marinilactibacillus gen. nov.}

Marinilactibacillus (Ma.ri.ni.lac.ti.ba.cil'lus. L. adj. marinus marine; L. n. lactis milk; L. n. bacillus a small rod; N.L. masc. n. Marinilactibacillus marine lactic acid rodlet).

Cells are Gram-positive, non-sporulating, straight rods, occurring singly, in pairs or in short chains. Motile with peritrichous flagella. Catalase and oxidase-negative. Negative for nitrate reduction and gelatin liquefaction. Ammonia is weakly produced from L-arginine. Slightly halophilic and highly halotolerant; the optimum $\mathrm{NaCl}$ concentration for growth is $2 \cdot 0-3 \cdot 75 \%(\mathrm{w} / \mathrm{v})$ with a range of 0 to $17 \cdot 0-20 \cdot 5 \%$ $(\mathrm{w} / \mathrm{v})$ (depending on the strain). Alkaliphilic; the optimum $\mathrm{pH}$ for growth is $8 \cdot 5-9 \cdot 0$ with a range of $6 \cdot 0-10 \cdot 0$. Growth occurs between -1.8 and $40-45{ }^{\circ} \mathrm{C}$ with an optimum temperature of $37-40^{\circ} \mathrm{C} . \mathrm{L}(+)$ Lactic acid is the major end product from $\mathrm{D}(+)$ glucose; trace to small amounts of formate, acetate and ethanol are produced with a molar ratio of approximately $2: 1: 1$, without gas formation. The peptidoglycan is of the A4 $\beta$, Orn-D-Glu type. Cellular fatty acids are primarily of the straight-chain saturated and monounsaturated even-carbon-numbered types. The major fatty acids are $\mathrm{C} 16: 0, \mathrm{C} 16: 1 \Delta 9, \mathrm{C} 18: 0$ and $\mathrm{C} 18: 1 \Delta 9$ (oleic acid). Respiratory quinones are absent. The $\mathrm{G}+\mathrm{C}$ content of the DNA is $34 \cdot 6-36 \cdot 2 \mathrm{~mol} \%$. The type species of the genus is Marinilactibacillus psychrotolerans sp. nov.

\section{Description of Marinilactibacillus psychrotolerans sp. nov.}

Marinilactibacillus psychrotolerans (psy.chro.to'le.rans. Gr. adj. psychros cold; L. part. adj. tolerans tolerating; N.L. adj. psychrotolerans tolerating cold temperature).

The species has all of the characteristics that define the genus. In addition, it has the characteristics described below. Deep colonies in agar medium are pale yellow, opaque and lenticular with diameters of $2-4 \mathrm{~mm}$. Cells are $0 \cdot 4-0 \cdot 5 \times 2 \cdot 3-4 \cdot 5 \mu \mathrm{m}$ and elongated in older cultures. Grows evenly throughout a column of semi-solid agar medium. Acid is produced from a fairly wide range of carbohydrates, sugar alcohols and related carbon compounds (Table 1). Sodium gluconate is fermented without gas production. The $\mathrm{G}+\mathrm{C}$ content of the DNA of strain $\mathrm{M} 13-2^{\mathrm{T}}$ is $36 \cdot 2 \mathrm{~mol} \%$. Isolated from a living sponge, raw Japanese ivory shell and decomposing alga. The type strain has been deposited at the IAM Culture Collection, the Institute of Molecular and Cellular Biosciences, The
University of Tokyo, Tokyo, Japan, the NITE Biological Resource Center (NBRC), National Institute of Technology and Evaluation, Kisarazu, Japan, the National Collections of Industrial, Food and Marine Bacteria (NCIMB), Aberdeen, UK and the Nodai Culture Collection Center (NRIC), Tokyo University of Agriculture, Tokyo, Japan, under the accession numbers IAM $14980^{\mathrm{T}}$, NBRC $100002^{\mathrm{T}}$, NCIMB $13873^{\mathrm{T}}$ and NRIC $0510^{\mathrm{T}}$, respectively.

\section{ACKNOWLEDGEMENTS}

We are grateful to Masayuki Suzuki, Mitsui Norin Co. Ltd, for the fatty acid analysis, Toshimori Kadokura, Faculty of Applied Bio-Science, Tokyo University of Agriculture, for the cell wall amino acid analysis, Yuko Itamiya and Shihomi Ishizaki, Faculty of Applied Bio-Science, Tokyo University of Agriculture, for technical assistance, and the Institute for Fermentation, Osaka (IFO), Deutsche Sammlung von Mikroorganismen und Zellkulturen GmbH (DSMZ) and the National Collections of Industrial, Food and Marine Bacteria (NCIMB) for supplying the type and reference strains.

\section{REFERENCES}

Aguirre, M., Morrison, D., Cookson, B. D., Gay, F. W. \& Collins, M. D. (1993). Phenotypic and phylogenetic characterization of some Gemella-like organisms from human infections: description of Dolosigranulum pigrum gen. nov., sp. nov. J Appl Bacteriol 75, 608-612.

Alumni Association of The Institute of Medical Sciences, The University of Tokyo (editors) (1988). Biseibutsugaku Jissyhu Teiyo (Manual for Practical Microbiology) (in Japanese). Tokyo: Maruzen.

Axelsson, L. T. (1993). Lactic acid bacteria: classification and physiology. In Lactic Acid Bacteria, pp. 1-63. Edited by S. Salminen \& A. von Wright. New York: Marcel Dekker.

Brosius, J., Palmer, J. L., Kennedy, J. P. \& Noller, H. F. (1978). Complete nucleotide sequence of a $16 \mathrm{~S}$ ribosomal RNA gene from Escherichia coli. Proc Natl Acad Sci U S A 75, 4801-4805.

Burton, H. R. (1980). Methane in a saline Antarctic lake. In Biochemistry of Ancient and Modern Environments, pp. 243-251. Edited by P. A. Trudinger \& M. R. Walter. Canberra: Australian Academy of Science.

Carlsson, J. \& Griffith, C. J. (1974). Fermentation products and bacterial yields in glucose-limited and nitrogen-limited cultures of streptococci. Arch Oral Biol 19, 1105-1109.

Collins, M. D., Farrow, J. A. E., Phillips, B. A., Ferusu, S. \& Jones, D. (1987). Classification of Lactobacillus divergens, Lactobacillus piscicola, and some catalase-negative, asporogenous, rod-shaped bacteria from poultry in a new genus, Carnobacterium. Int J Syst Bacteriol 37, 310-316.

Duckworth, A. W., Grant, W. D., Jones, B. E. \& van Steenbergen, R. (1996). Phylogenetic diversity of soda lake alkaliphiles. FEMS Microbiol Ecol 19, 181-191.

Ezaki, T., Hashimoto, Y. \& Yabuuchi, E. (1989). Fluorometric deoxyribonucleic acid-deoxyribonucleic acid hybridization in microdilution wells as an alternative to membrane filter hybridization in which radioisotopes are used to determine genetic relatedness among bacterial strains. Int J Syst Bacteriol 39, 224-229.

Felsenstein, J. (1985). Confidence limits on phylogenies: an approach using the bootstrap. Evolution 39, 783-791.

Franzmann, P. D., Höpfl, P., Weiss, N. \& Tindall, B. J. (1991). Psychrotrophic, lactic acid-producing bacteria from anoxic waters in 
Ace Lake, Antarctica; Carnobacterium funditum sp. nov. and Carnobacterium alterfunditum sp. nov. Arch Microbiol 156, 255-262.

Gatesoupe, F. J. (1999). The use of probiotics in aquaculture. Aquaculture 180, 147-165.

Goto, K., Matsubara, H., Mochida, K., Matsumura, T., Hara, Y., Niwa, M. \& Yamasato, K. (2002). Alicyclobacillus herbarius sp. nov., a novel bacterium containing $\omega$-cycloheptane fatty acids, isolated from herbal tea. Int J Syst Evol Microbiol 52, 109-113.

Gunsalus, I. C. \& Niven, C. F., Jr (1942). The effect of $\mathrm{pH}$ on the lactic acid fermentation. $J$ Biol Chem 145, 131-136.

Hasegawa, T., Takizawa, M. \& Tanida, S. (1983). A rapid analysis for chemical grouping of aerobic actinomycetes. J Gen Appl Microbiol 29, 319-322.

International Committee on Systematics of Prokaryotes (2001). Notification that new names and new combinations have appeared in volume 51, part 3, of the IJSEM. Int J Syst Evol Microbiol 51, 1231-1233.

Janssen, P. H., Evers, S., Rainey, F. A., Weiss, N., Ludwig, W., Harfoot, C. G. \& Schink, B. (1995). Lactosphaera gen. nov., a new genus of lactic acid bacteria, and transfer of Ruminococcus pasteurii Schink 1984 to Lactosphaera pasteurii comb. nov. Int J Syst Bacteriol 45, 565-571.

Jones, B. E., Grant, W. D., Collins, N. C. \& Mwatha, W. E. (1994). Alkaliphiles: Diversity and identification. In Bacterial Diversity and Systematics, pp. 195-230. Edited by F. G. Priest, A. RamosCormenzana \& B. J. Tindall. New York: Plenum.

Kawahara, K., Uchida, K. \& Aida, K. (1979). Direct hydroxylation in the biosynthesis of hydroxy fatty acid in lipid of a Pseudomonas ovalis. Biochim Biophis Acta 572, 1-8.

Kimura, M. (1980). A simple method for estimating evolutionary rates of base substitutions through comparative studies of nucleotide sequences. J Mol Evol 16, 111-120.

Komagata, K. \& Suzuki, K. (1987). Lipid and cell wall analysis in bacterial systematics. Methods Microbiol 19, 161-207.

Kushner, D. J. (1978). Life in high salt and solute concentrations: halophilic bacteria. In Microbial Life in Extreme Environments, pp. 318-346. Edited by D. J. Kushner. London, New York: Academic Press.

Kushner, D. J. \& Kamekura, M. (1988). Physiology of halophilic eubacteria. In Halophilic Bacteria, vol. I, pp. 109-140. Edited by F. Rodríguez-Valera. Boca Raton, FL: CRC Press.

Lindmark, D. G., Paolella, P. \& Wood, N. P. (1969). The pyruvate formate-lyase system of Streptococcus faecalis. J Biol Chem 244, 3605-3612.

Marmur, J. (1961). A procedure for the isolation of deoxyribonucleic acid from micro-organisms. J Mol Biol 3, 208-218.

Masuda, N., Nakaya, S., Burton, H. R. \& Torii, T. (1988). Trace element distributions in some saline lakes of the Vestfold Hills, Antarctica. Hydrobiologia 165, 103-114.

Mees, R. H. (1934). Onderzoekingen over de biersarcina. PhD Thesis, Technical University, Delft, The Netherlands.

Murray, R. G. E., Doetsch, R. N. \& Robinow, C. F. (1994). Determination and cytological light microscopy. In Methods for General and Molecular Bacteriology, pp. 21-41. Edited by P. Gerhardt, R. G. E. Murray, W. A. Wood \& N. R. Kreig, Washington, DC: American Society for Microbiology.

Nakagawa, A. \& Kitahara, K. (1959). Taxonomic studies on the genus Pediococcus. J Gen Appl Microbiol 3, 95-126.

Ntougias, S. \& Russell, N. J. (2001). Alkalibacterium olivoapovliticus gen. nov., sp. nov., a new obligately alkaliphilic bacterium isolated from edible-olive wash-waters. Int $J$ Syst Evol Microbiol 51, $1161-1170$.

Okada, S., Uchimura, T. \& Kozaki, M. (1992). Nyusankin Jikken Manyuaru (Laboratory Manual for Lactic Acid Bacteria) (in Japanese). Tokyo: Asakura-shoten.

Rhee, S. K. \& Pack, M. Y. (1980). Effect of environmental pH on fermentation balance of Lactobacillus bulgaricus. J Bacteriol 144, 217-221.

Ringø, E. \& Gatesoupe, F.-J. (1998). Lactic acid bacteria in fish: a review. Aquaculture 160, 177-203.

Saito, H. \& Miura, K. (1963). Preparation of transforming deoxyribonucleic acid by phenol treatment. Biochim Biophys Acta 72, 619-629.

Saitou, N. \& Nei, M. (1987). The neighbor-joining method: a new method for reconstructing phylogenetic trees. Mol Biol Evol 4, 406-425.

Sano, H., Sakai, M. \& Nishijima, M. (1996). Application of MS to the search of the products from marine bacteria. Sitsuryo Bunseki (J Mass Spectrom Soc Jpn) 44, 377-391 (in Japanese).

Somogyi, M. (1945). A new reagent for the determination of sugars. J Biol Chem 160, 61-68.

Stackebrandt, E., Schumann, P., Swiderski, J. \& Weiss, N. (1999). Reclassification of Brevibacterium incertum (Breed 1953) as Desemzia incerta gen. nov., comb. nov. Int J Syst Bacteriol 49, 185-188.

Suto, T., Fujimura, Y. \& Kuraishi, H. (1982). Analysis of fatty acids. In Biseibutsuno Kagakubunrui Jikkenho (Manual of Microbial Chemosystematics), pp. 155-172 (in Japanese). Edited by K. Komagata. Tokyo: Gakkai Shuppan Senta (Japan Scientific Societies Press).

Takahashi, S., Abbe, K. \& Yamada, T. (1982). Purification of pyruvate formate-lyase from Streptococcus mutans and its regulatory properties. J Bacteriol 149, 1034-1040.

Tamaoka, J. \& Komagata, K. (1984). Determination of DNA base composition by reverse-phase high-performance liquid chromatography. FEMS Microbiol Lett 25, 125-128.

Thomas, T. D., Ellwood, D. C. \& Longyear, V. M. C. (1979). Change from homo- to heterolactic fermentation by Streptococcus lactis resulting from glucose limitation in anaerobic chemostat cultures. J Bacteriol 138, 109-117.

Thompson, J. D., Gibson, T. J., Plewniak, F., Jeanmougin, F. \& Higgins, D. G. (1997). The Clustal $X$ windows interface: flexible strategies for multiple sequence alignment aided by quality analysis tools. Nucleic Acids Res 24, 4876-4882.

Vogel, R. F., Böcker, G., Stolz, P. \& 7 other authors (1994). Identification of lactobacilli from sourdough and description of Lactobacillus pontis sp. nov. Int J Syst Bacteriol 44, 223-229.

Williams, R. A. D. \& Sadler, S. A. (1971). Electrophoresis of glucose6-phosphate dehydrogenase, cell wall composition and the taxonomy of heterofermentative lactobacilli. J Gen Microbiol 65, 351-358.

Yamada, T. \& Carlsson, J. (1975). Regulation of lactate dehydrogenase and change of fermentation products in Streptococci. J Bacteriol 124, 55-61.

Yamada, Y. \& Kuraishi, H. (1982). Analysis of ubiquinones and menaquinones. In Biseibutsuno Kagakubunrui Jikkenho (Manual of Microbial Chemosystematics), pp. 143-155 (in Japanese). Edited by K. Komagata. Tokyo: Gakkai Shuppan Senta (Japan Scientific Societies Press).

Yanagi, M. \& Yamasato, K. (1993). Phylogenetic analysis of the family Rhizobiaceae and related bacteria by sequencing of $16 \mathrm{~S}$ rRNA gene using PCR and DNA sequencer. FEMS Microbiol Lett 107, 115-120. 